\title{
SIAE wt Allele
}

National Cancer Institute

\section{Source}

National Cancer Institute. SIAE wt Allele. NCI Thesaurus. Code C91283.

Human SIAE wild-type allele is located in the vicinity of $11 \mathrm{q} 24$ and is approximately $38 \mathrm{~kb}$ in length. This allele, which encodes sialate O-acetylesterase protein, is involved in the modification of sialic acid. 